\title{
Preparation and Characterization of High Purity Anhydrous $\beta$-Lactose from $\alpha$-Lactose Monohydrate at Mild Temperature
}

\author{
Ana L. López-Pablos $\mathbb{D},{ }^{1,2}$ César C. Leyva-Porras $\mathbb{D},{ }^{3}$ Macrina B. Silva-Cázares $\mathbb{D},{ }^{1,2}$ \\ Francisco E. Longoria-Rodríguez $\left(\mathbb{D},{ }^{4}\right.$ Sergio A. Pérez-García $(\mathbb{D})^{4}$ \\ Ángel A. Vértiz-Hernández, ${ }^{2}$ and María Z. Saavedra-Leos $\mathbb{1 D}^{2}$ \\ ${ }^{1}$ Doctorado Institucional en Ingeniería y Ciencia de Materiales (DICIM), Sierra Leona 530, Col. Lomas, 2a. Sección, \\ 78210 San Luis Potosí, SLP, Mexico \\ ${ }^{2}$ Coordinación Académica Región Altiplano, Universidad Autónoma de San Luis Potosí, Carretera a Cedral Km. 5+600, \\ Ejido San José de las Trojes, 78700 Matehuala, SLP, Mexico \\ ${ }^{3}$ Centro de Investigación en Materiales Avanzados S.C. (CIMAV), Miguel de Cervantes No. 120, Complejo Industrial Chihuahua, \\ 31136 Chihuahua, CHIH, Mexico \\ ${ }^{4}$ Centro de Investigación de Materiales Avanzados S.C. (CIMAV-Mty), Alianza Norte No. 202, Parque de Investigación e Innovación \\ Tecnológica (PIIT), 66600 Apodaca, NL, Mexico
}

Correspondence should be addressed to María Z. Saavedra-Leos; zenaida.saavedra@uaslp.mx

Received 2 February 2018; Accepted 4 April 2018; Published 13 May 2018

Academic Editor: Pazhanichamy Kalailingam

Copyright (C) 2018 Ana L. López-Pablos et al. This is an open access article distributed under the Creative Commons Attribution License, which permits unrestricted use, distribution, and reproduction in any medium, provided the original work is properly cited.

\begin{abstract}
Lactose is a disaccharide of importance in humans dietary, food products, and the pharmaceutical industry. From the existing isomeric forms, $\beta$-lactose is rarely found in nature. Thus, in this work, a simple methodology to obtain anhydrous $\beta$-lactose $(\beta \mathrm{L})$ from $\alpha$-lactose monohydrate $\left(\alpha \mathrm{L} \cdot \mathrm{H}_{2} \mathrm{O}\right)$ is presented. The $\alpha \mathrm{L} \cdot \mathrm{H}_{2} \mathrm{O}$ powder was dispersed into a basic alcoholic solution (72 hours), at controlled conditions of temperature $\left(27,29,31\right.$, and $\left.32^{\circ} \mathrm{C}\right)$, without stirring. The slurry was dried at room temperature and characterized. Fourier transform infrared spectroscopy showed the formation of $\beta \mathrm{L}$ for the samples prepared at 29 and $32^{\circ} \mathrm{C}$. Raman spectroscopy confirmed this result and suggested the occurrence of crystalline $\beta \mathrm{L}$. Rietveld refinement of the X-ray diffraction patterns was employed to identify and quantify the composition of the isomers. The samples prepared at 29 and $31^{\circ} \mathrm{C}$ showed the formation of pure $\beta \mathrm{L}$, while those at 27 and $32^{\circ} \mathrm{C}$ showed the presence of $\alpha \mathrm{L} \cdot \mathrm{H}_{2} \mathrm{O}$ and a mixture of the two isomers, respectively. The morphology of the powders was studied by scanning electron microscopy, observing the formation of irregular shape $\alpha \mathrm{L} \cdot \mathrm{H}_{2} \mathrm{O}$ particles and axe-like $\beta \mathrm{L}$ particles. Clearly, with this methodology, it was possible to obtain pure, crystalline, and anhydrous $\beta \mathrm{L}$ at mild temperature.
\end{abstract}

\section{Introduction}

Lactose (4-O- $\beta$-D-galactopyranosyl-D-glucopyranose) is found exclusively in the milk of mammals and is composed of molecules of galactose and glucose, linked by a $\beta$-glycosidic bond $(1,4)$. Since the anomeric carbon of glucose is free, this disaccharide exhibits the features of reducing sugars; that is, the chain configuration is opened by the formation of an aldehyde group [1]. Lactose is used as an additive in many foods, besides being an excipient of numerous drugs. For example, in the food industry, it is used as a commercial additive because of its texture, flavor, and adhesive properties [2]. In the pharmaceutical industry, lactose is employed as excipient in more than $20 \%$ of the total of prescription drugs and in $65 \%$ of the over-the-counter medications [3]. When used as excipient in drugs, lactose is the substance where the active ingredient is dispersed and preserved in a stable state $[4,5]$. This disaccharide exists in two isomeric forms, $\alpha$-lactose, and $\beta$-lactose, which shows the phenomenon of mutarotation, that is, the interconversion of the stereocenters [6]. Lactose exhibits three polymorphs (anhydrous forms) and a solvate (hydrated form): anhydrous $\beta$-lactose $(\beta \mathrm{L})$, 
TABLE 1: Summary of the methodologies reported for the conversion of $\alpha \mathrm{L} \cdot \mathrm{H}_{2} \mathrm{O}$ into $\beta \mathrm{L}$.

\begin{tabular}{|c|c|c|c|}
\hline Methodology & Results & Characterization technique & Reference \\
\hline $\begin{array}{l}\text { Starting material: } \alpha \mathrm{L} \cdot \mathrm{H}_{2} \mathrm{O} \text {. } \\
\text { Solvent: sodium hydroxide in methanol. } \\
\text { Temperature: room temperature, and boiling } \\
\text { temperature of methanol. } \\
\text { Reaction time }(h): 2-10 . \\
\text { Post processing: filtering and vacuum drying. }\end{array}$ & Crystalline $\beta \mathrm{L}$, purity of $93.6 \%$. & Gas-liquid chromatography & [12] \\
\hline $\begin{array}{l}\text { Starting material: } \alpha \mathrm{L} \cdot \mathrm{H}_{2} \mathrm{O} \text {. } \\
\text { Solvent: potassium methoxide in methanol. } \\
\text { Temperature: room temperature, and boiling } \\
\text { temperature of methanol. } \\
\text { Reaction time }(h): 0.7-24 \text {. } \\
\text { Post processing: filtering, washing, and vacuum drying } \\
\text { by } 16 \mathrm{~h} \text {. }\end{array}$ & Crystalline $\beta \mathrm{L}$, purity of $98 \%$. & $\begin{array}{l}\text { Differential scanning } \\
\text { calorimetry (DSC) }\end{array}$ & {$[13]$} \\
\hline $\begin{array}{l}\text { Starting material: } \alpha \mathrm{L} \cdot \mathrm{H}_{2} \mathrm{O} \text {. } \\
\text { Solvent: potassium methoxide or potassium hydroxide } \\
\text { in methanol. } \\
\text { Temperature: room temperature, and boiling } \\
\text { temperature of methanol. } \\
\text { Reaction time }(h): 3-140 . \\
\text { Post processing: filtering, washing, and vacuum drying } \\
\text { by } 16 \text { h. }\end{array}$ & Crystalline $\beta \mathrm{L}$, purity of $95 \%$. & Gas-liquid chromatography & {$[15]$} \\
\hline
\end{tabular}

unstable hygroscopic anhydrous $\alpha$-lactose $\left(\alpha \mathrm{L}_{\mathrm{H}}\right)$, stable anhydrous $\alpha$-lactose $\left(\alpha \mathrm{L}_{\mathrm{S}}\right)$, and $\alpha$-lactose monohydrate $\left(\alpha \mathrm{L} \cdot \mathrm{H}_{2} \mathrm{O}\right)$ [3, 7]. In addition to these polymorphs, there are another two which are classified based on the solid state, crystalline anhydrous mixture of $\alpha$ - and $\beta$-lactose and amorphous anhydrous mixture of $\alpha$ - and $\beta$-lactose [8]. The study of the polymorphs of lactose is of great interest because several physical properties, such as solubility, density, stability, shelf life, dissolution rate, and bioavailability, depend on the crystalline structure [9]. Several works focused on the study of the crystalline forms have been concerned with the following: (i) the properties characterization of polymorphs with the aim of predicting their stability and (ii) the preparation of the different polymorphs from $\alpha \mathrm{L} \cdot \mathrm{H}_{2} \mathrm{O}$, especially the $\beta \mathrm{L}$, since it is thermodynamically stable, just after the $\alpha \mathrm{L} \cdot \mathrm{H}_{2} \mathrm{O}$. For example, Kirk et al. (2007) provided a guide for identifying the physical and chemical characteristics of lactose polymorphs [10]. Figura and Epple (1995) performed a study on the thermal and physical characterization of the different polymorphs of lactose [11]. Olano and Ríos (1978) and Parrish et al. (1979) reported obtaining the $\beta \mathrm{L}$ from the $\alpha \mathrm{L} \cdot \mathrm{H}_{2} \mathrm{O}$ in alkaline alcoholic solutions, with conversions of $90-93 \%$ and $98 \%$, respectively $[12,13]$. In addition, authors such as Olano (1978) obtained the $\beta \mathrm{L}$ with a purity of $90 \%$ [14]. More recently, Chen et al. (2015) and Kirk et al. (2007) have also contributed to obtaining the $\beta \mathrm{L}$, based on the methodology reported elsewhere $[9,10]$. Table 1 summarizes the methodologies reported for the conversion of $\alpha \mathrm{L} \cdot \mathrm{H}_{2} \mathrm{O}$ into $\beta \mathrm{L}$. Although there are a large number of works reported which are focused on the preparation and characterization of the polymorphs of lactose, to the best of our knowledge, a high conversion of the $\alpha \mathrm{L} \cdot \mathrm{H}_{2} \mathrm{O}$ into $\beta \mathrm{L}$ has not been reported so far. Therefore, in the present work, a simple methodology to obtain a relatively high conversion of $\beta \mathrm{L}(>99.9 \%)$, as well as the physicochemical and thermal characterization, is reported. This methodology allows obtaining $\beta \mathrm{L}$ in an alcoholic solution in a narrow range of temperature, while avoiding the stirring and vacuum-drying steps.

\section{Experimental}

2.1. Materials. $\alpha$-Lactose monohydrate $\left(\alpha \mathrm{L} \cdot \mathrm{H}_{2} \mathrm{O}\right.$, purity $\geq$ $99 \%$, Sigma) was employed as the starting material and precursor of the $\beta \mathrm{L}$, while sodium hydroxide ( $>98 \%$, Macron Fine Chemicals) and methanol (HPLC grade, Sigma-Aldrich) were used in the preparation of the inorganic salt alcoholic solution.

2.2. Preparation of $\beta$-Lactose. Figure 1 shows a schematic representation of the methodologies described by Olano and Ríos [12] and Parrish et al. [13]. In these methodologies, the $\alpha \mathrm{L} \cdot \mathrm{H}_{2} \mathrm{O}$ was used as initial reagent and dissolved in a basic methanol solution employed as the reacting media for the conversion of this polymorph into anhydrous $\beta \mathrm{L}$. However, Parrish et al. carried out a preliminary treatment in anhydrous sodium acetate solution and acetic anhydride in order to produce two intermediates ( $\alpha$ - and $\beta$-lactose octaacetates), which according to these authors it was required to achieve higher yields. Figure 1 also summarizes the steps followed in this work. The $\beta \mathrm{L}$ was prepared in batches, in which the $\alpha$-lactose monohydrate was placed in a $0.2 \%$ (wt $\%$ ) sodium hydroxide methanol solution, in a $1: 10$ ratio $(\alpha-$ lactose to methanol solution). Each batch was placed in an incubator at $27,29,31$, and $32^{\circ} \mathrm{C}$, respectively, for 72 hours without agitation. After the reaction time, the solutions were filtered and washed and the wet powder was dried at room temperature in a desiccator. According to Garnier et al. 


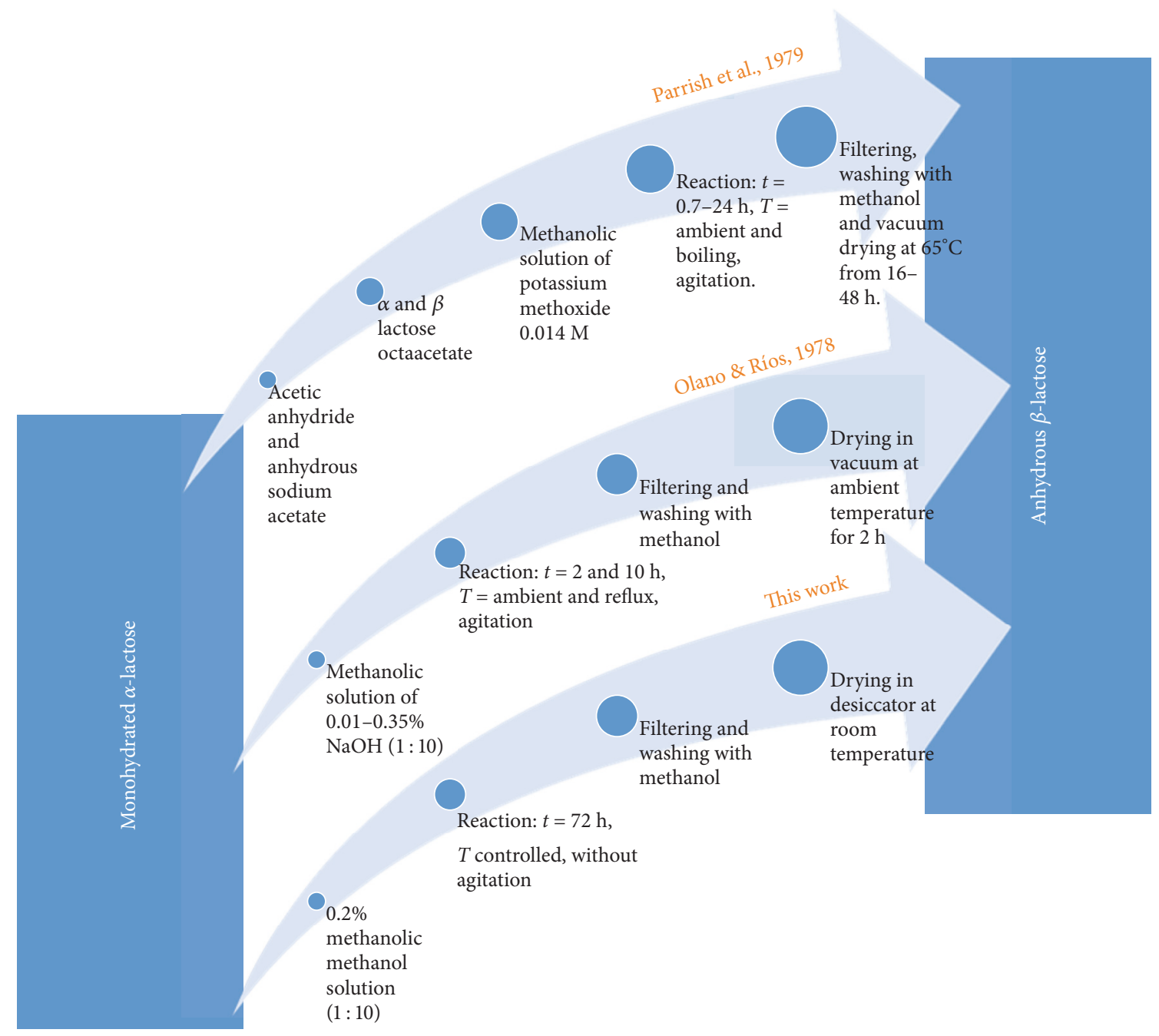

FIGURE 1: Schematic representation of the methodologies reported by Parrish et al. (1979), Olano \& Ríos (1978), and this work.

(2002), static conditions, that is, without stirring the solution, promote the nucleation and growth of $\beta$-lactose crystals in the solution [16]. The methodology implemented in this work overcomes the stirring and vacuum-drying steps, which are required to obtain the $\beta$-lactose.

2.3. Physicochemical Characterization. The dried powders were characterized by Fourier transform infrared (FTIR) spectroscopy, in a Thermo Scientific Nicolet iS50 FTIR spectrophotometer, coupled to a Smart Orbit accessory with total attenuated reflectance (ATR) with a diamond crystal. Data were in a range of 4000 to $600 \mathrm{~cm}^{-1}$ and processed by Omnic 9.3.32 software. Raman spectroscopy was carried out using a Horiba LabRam HR Evolution instrument with a Jobin Yvon spectrometer. A red laser of $\mathrm{He}-\mathrm{Ne}$ with a wavelength of $633 \mathrm{~nm}$ was used. An Olympus BXFM-ILHS microscope with a 100x objective lens was used to focus the laser beam on the sample. The Raman spectra were collected in a range of 50 to $3350 \mathrm{~cm}^{-1}$.

2.4. $\beta$-Lactose Purity by X-Ray Diffraction. The characterization of the crystalline phases present within the sample was carried out using the X-ray diffraction (XRD) technique, using an Empyrean diffractometer, PANalytical, with

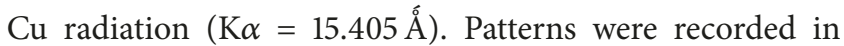
the range of $2 \theta$ of $5-90^{\circ}$, with a step size of $0.016^{\circ}$ and 59.69 s per step. For the XRD analysis, the solid sample was placed in a zero-background sample holder of amorphous silicon. The semiquantitative analysis of the crystalline phases present within the material was carried out following the Rietveld method, using the HighScore Plus Software version 3.0.5 (PANalytical B.V.). The Rietveld method consists of adjusting the experimental intensities corresponding to the $\mathrm{X}$-ray diffraction pattern according to a theoretical model, using the least squares method, until the best fit between both is achieved. The diffraction pattern calculated is based on a model that includes structural, microstructural, and instrumental information. The quantity to be minimized in Rietveld refinement of the diffraction pattern is the residual $\left(S_{y}\right)$, which is described according to the following:

$$
S_{y}=\sum i W_{i}\left(y_{i}-y_{\mathrm{cal}}\right)^{2},
$$




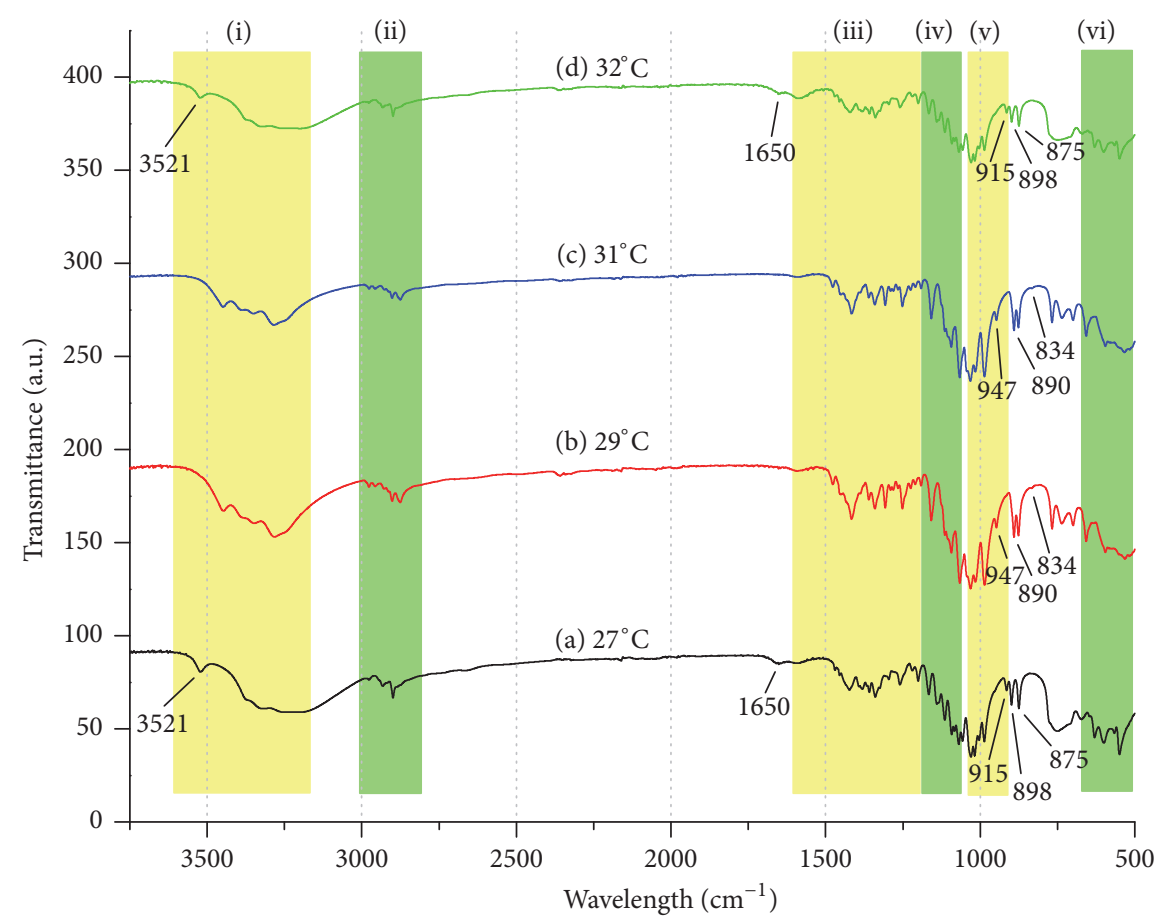

FIGURE 2: FTIR spectra of samples prepared at different temperatures. Temperature is indicated on each curve.

where $W_{i}=1 / y_{i}, y_{i}$ is the experimental intensity at the $i$ th step, $y_{\text {cal }}$ is the calculated intensity at the $i$ th step, and the sum is done over all the data point of the diffraction pattern [17].

2.5. Thermal Analysis. Thermogravimetric (TGA) and differential thermal analyses (DTA) were carried out in a simultaneous TGA-DTA SDT Q600 (TA Instruments, USA). Baseline was calibrated with Indium with a melting temperature of $156.6^{\circ} \mathrm{C}$ and melting enthalpy of $28.47 \mathrm{~J} / \mathrm{g}$. Samples of 5-10 $\mathrm{mg}$ were encapsulated in standard aluminum pans. Thermograms were recorded at a heating rate of $5^{\circ} \mathrm{C} / \mathrm{min}$ over a range of $25-500^{\circ} \mathrm{C}$. Using the Universal Analysis 2000( software, several features from the curves were identified: mass loss $(\% \mathrm{w} / \mathrm{w})$, melting temperature $\left(T_{m}\right)$, and degradation temperature $\left(T_{d}\right)$. A modulated DSC Q200 (TA Instruments, USA) equipped with an RCS90 cooling system was employed for accurately determining the different thermal events such as the glass transition temperature $\left(T_{g}\right)$, melting $\left(T_{m}\right)$, and degradation $\left(T_{d}\right)$. Instrument was calibrated with Indium for melting temperature and enthalpy, while Sapphire was used as the standard for heat capacity $\left(C_{p}\right)$. Samples ranging in $5-10 \mathrm{mg}$ were encapsulated in Tzero ${ }^{\circledR}$ aluminum pans. Thermograms were acquired at a temperature range of -90 to $250^{\circ} \mathrm{C}$, with a modulation period of $40 \mathrm{~s}$ and amplitude of $1.5^{\circ} \mathrm{C}$. Each experiment was repeated three times.

2.6. Scanning Electron Microscopy (SEM). A scanning electron microscope JSM-6010/LV (JEOL, Japan) operated at $15 \mathrm{kV}$ in low vacuum mode was employed for observing the morphology of the powders. A portion of each sample was manually dispersed on a carbon film and observed without any further treatment.

\section{Results and Discussion}

3.1. Chemical Characterization of Lactose Polymorphs by FTIR. Samples prepared at different temperatures were analyzed using the Fourier transform infrared spectrometry (FTIR), to elucidate the formation of the polymorph. The resulting spectra are presented in Figure 2, where the colored rectangles differentiate the characteristic vibrations of the lactose molecule: (i) the symmetric stretching vibration of the hydroxyl groups $(\mathrm{OH})$ between $3600-3200 \mathrm{~cm}^{-1}$; (ii) the stretching vibrations of the $\mathrm{CH}$ groups presented in the glucose and galactose molecules at $3000-2800 \mathrm{~cm}^{-1}$; (iii) the rocking and wagging vibrations of the $\mathrm{CH}, \mathrm{OH}$, and $\mathrm{CH}_{2}$ groups at $1600-1200 \mathrm{~cm}^{-1}$; (iv) the flexion vibration of the glycosidic bond (C-O-C) at $1200-1070 \mathrm{~cm}^{-1}$; (v) the stretching of the CO of the glycosidic bond at $1142-953 \mathrm{~cm}^{-1}$; (vi) the deformation vibrations of the glycosidic bond at $633-477 \mathrm{~cm}^{-1}$. Additionally, the spectra from samples prepared at 27 and $32^{\circ} \mathrm{C}$ (Figure 2 (a) and (d)) showed the characteristic bands of $\alpha \mathrm{L} \cdot \mathrm{H}_{2} \mathrm{O}$ at 915,898 , and $874 \mathrm{~cm}^{-1}$, while those from samples prepared at 29 and $31^{\circ} \mathrm{C}$ (Figure 2 (b) and (c)) displayed the distinctive bands of $\beta \mathrm{L}$ at 947,890 , and $834 \mathrm{~cm}^{-1}$. According to Listiohadi et al. (2009) the bands located at $3600-3200 \mathrm{~cm}^{-1}$ correspond to the stretching of the $\mathrm{OH}$ groups of the lactose molecule, while the vibrations at $1650 \mathrm{~cm}^{-1}$ are related to the flexion of the $\mathrm{OH}$ groups of the crystallized water molecules [18]. Conversely, Kirk et al. (2007) reported that the bands at 3500 and $1654 \mathrm{~cm}^{-1}$, corresponded to the vibrations and distortion of the $\mathrm{OH}$ groups in water molecules, respectively [10]. The FTIR spectra reported in Figure 2 (a) and (d) showed the 


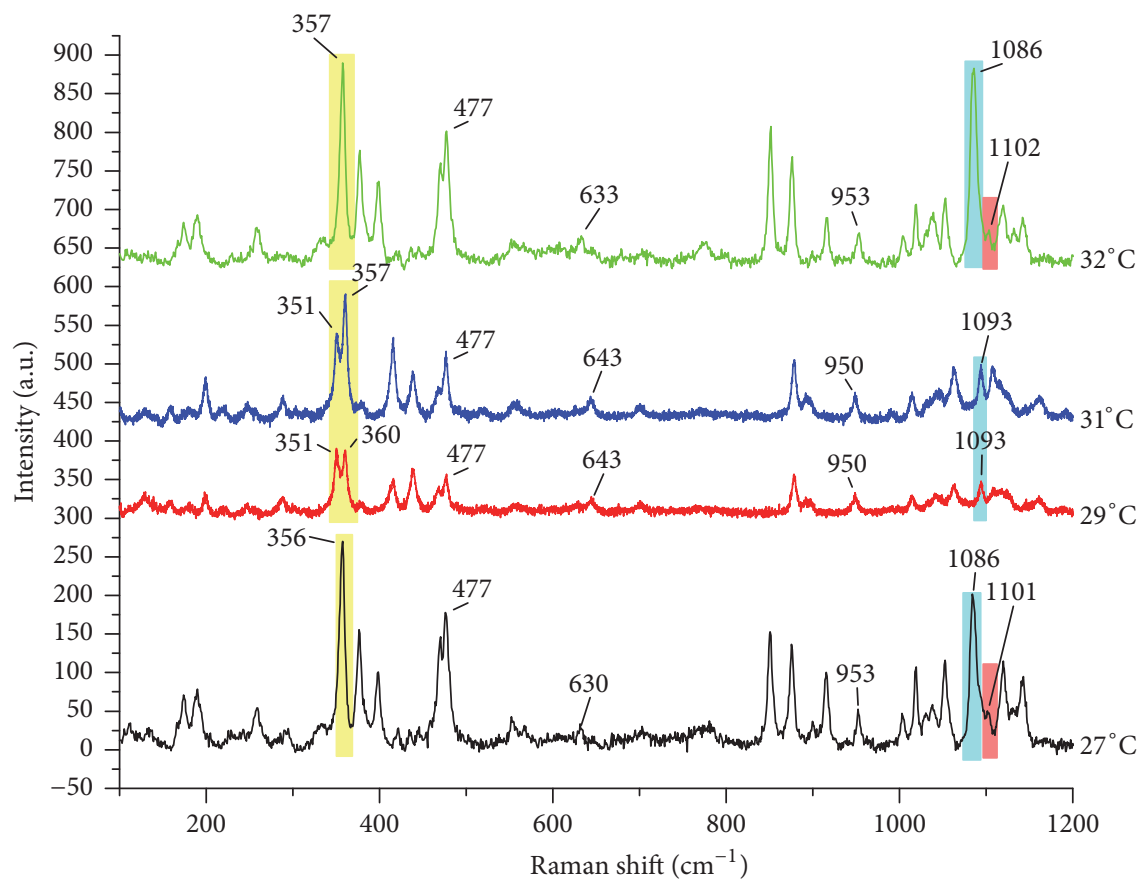

FIGURE 3: Raman spectra obtained for the samples prepared at the different temperatures, which is indicated on each curve.

presence of a broad band at $3500 \mathrm{~cm}^{-1}$ and a weak band at $1650 \mathrm{~cm}^{-1}$, while the spectra for Figure 2 (b) and (c) showed the absence of the bands. Thus, these observations confirmed the formation of anhydrous $\beta \mathrm{L}$ for the samples prepared at 29 and $32^{\circ} \mathrm{C}$. The spectra reported herein are similar to those reported by the British Pharmacopoeia [19] and Norris and Greenstreet [20], for $\alpha \mathrm{L} \cdot \mathrm{H}_{2} \mathrm{O}$, and $\beta \mathrm{L}$, respectively.

Furthermore, Listiohadi et al. [18] employed FTIR technique for differentiate the crystalline lactose from the amorphous. They observed differences in the FTIR spectra between the amorphous and crystalline lactose; that is, the crystalline lactose shows well-defined vibrations peaks, while, in the amorphous lactose, the peaks are broad and less intense [18]. Based on this, all the reported FTIR spectra showed welldefined and sharp vibration peaks, suggesting the formation of crystalline $\alpha \mathrm{L} \cdot \mathrm{H}_{2} \mathrm{O}$ at 27 and $32^{\circ} \mathrm{C}$ and crystalline $\beta \mathrm{L}$ at 29 and $31^{\circ} \mathrm{C}$.

3.2. Raman Spectroscopy. Raman spectroscopy is a characterization technique sensible to the chemical environment of a molecule; that is, with this tool it is possible to distinguish differences in the composition and the way atoms are bonded [21]. Figure 3 shows the Raman spectra obtained for the samples prepared at the different temperatures. All the spectra showed several sharp bands characteristic of the disaccharides. According to Wiercigroch et al. (2017), the lactose molecule presents many vibrations modes in the wavenumber range up to $800 \mathrm{~cm}^{-1}$, corresponding to the torsion of the ring and the deformation of O-C-C, O-C$\mathrm{O}$, and $\mathrm{C}-\mathrm{C}-\mathrm{O}$, while the high intensity of the vibration mode about $357 \mathrm{~cm}^{-1}$ is attributed to the twist-like vibrations of the $\mathrm{COOH}$ and $\mathrm{HOH}$ groups [22]. Kirk et al. (2007) concluded that Raman spectroscopy could be employed to differentiate the anomeric conformation of lactose by comparing the intensity of the vibration mode at $1100 \mathrm{~cm}^{-1}$ [10]. They observed the presence of a high intensity vibration mode at $1100 \mathrm{~cm}^{-1}$ in the $\alpha \mathrm{L} \cdot \mathrm{H}_{2} \mathrm{O}$ and the absence of this mode in the $\beta \mathrm{L}$. Wiercigroch et al. (2017) explained that the vibration at $1100 \mathrm{~cm}^{-1}$ was caused by the rotation of the C$\mathrm{O}-\mathrm{C}$ bond, which allows the formation of the anomeric bond [22]. Together with the vibration at $1100 \mathrm{~cm}^{-1}$, the vibration at $357 \mathrm{~cm}^{-1}$ must be presented, which is observed as a single peak in the $\alpha \mathrm{L} \cdot \mathrm{H}_{2} \mathrm{O}$ and as a double peak in the $\beta \mathrm{L}$ [10]. The Raman spectra reported in this work showed the presence of a sharp vibration mode at $1086 \mathrm{~cm}^{-1}$ for the samples prepared at 27 and $32^{\circ} \mathrm{C}$ and the less intense vibration mode about $1100 \mathrm{~cm}^{-1}$ for the samples prepared at 29 and $31^{\circ} \mathrm{C}$. The vibration mode at $357 \mathrm{~cm}^{-1}$ was observed as a single peak in the samples prepared at 27 and $32^{\circ} \mathrm{C}$ and as a high intensity double peak in the samples prepared at 29 and $31^{\circ} \mathrm{C}$. Evidently, these observations indicate the formation of the $\beta \mathrm{L}$ at the intermediate temperatures. In addition, the vibration about $1086-1100 \mathrm{~cm}^{-1}$ can be employed to identify the microstructure of lactose, that is, crystalline or amorphous, where the presence of the band indicates a crystalline structure [23]. All the samples showed a vibration band at $1086-1100 \mathrm{~cm}^{-1}$, suggesting the occurrence of crystalline $\alpha \mathrm{L} \cdot \mathrm{H}_{2} \mathrm{O}$ and $\beta \mathrm{L}$. The vibrations modes at 477 and $633 \mathrm{~cm}^{-1}$ were assigned to the deformation of the C-C-O group in the glycosidic bond [22]. According to Márquez et al. (2015) and Rodriguez Júnior et al. (2016), the vibration modes at 953 and $1142 \mathrm{~cm}^{-1}$ are originated from the stretching of the $\mathrm{CO}$ in the glycosidic bond $[24,25]$.

3.3. Polymorph Identification and Composition Determination by XRD. XRD technique and the Rietveld method were 


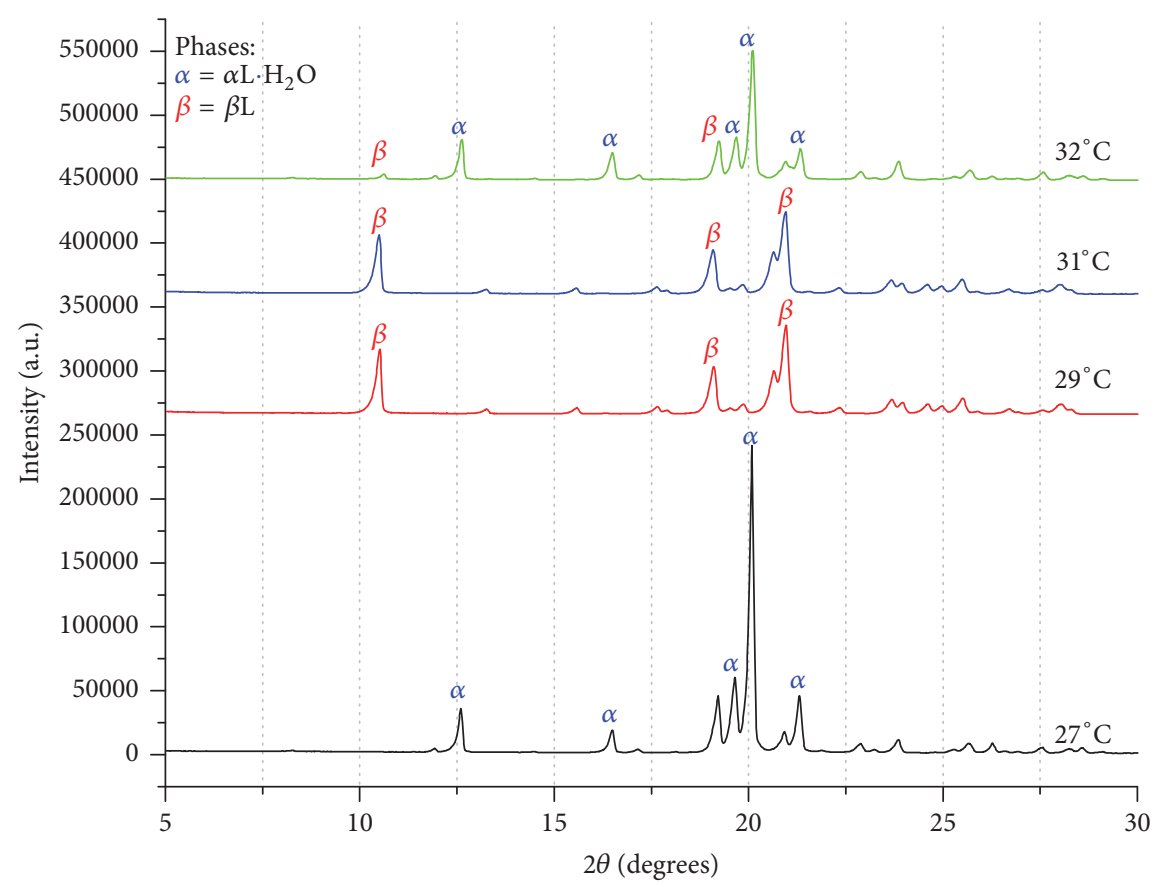

FIGURE 4: XRD diffractograms of the powders prepared at $27,29,31$, and $32^{\circ} \mathrm{C}$.

employed for identifying the distinct polymorphs $(\alpha$ and $\beta$ ) and determining the purity of the lactose powders. Figure 4 shows the diffractograms of the powders prepared at 27,29, 31 , and $32^{\circ} \mathrm{C}$. Overall, lactose samples showed well-defined and sharp peaks, typically observed in crystalline materials. The corresponding diffractograms of samples prepared at 27 and $32^{\circ} \mathrm{C}$ showed the distinctive reflections of the $\alpha$-lactose monohydrate polymorph located at $2 \theta$ angle of $12.5,16.4$, 19.5 , and $20.5^{\circ}$. All the reflections matched with those of $\alpha$ lactose, reported by the international center for diffraction data (ICDD) in the powder diffraction file PDF 00-024-1783 [26]. The results agree with those presented by Gombás et al. (2003), who studied the accuracy of the XRD technique, in the quantification of the crystallinity degree in amorphouscrystalline mixtures of lactose [27]. The samples prepared at 29 and $31^{\circ} \mathrm{C}$ showed the peaks corresponding to the anhydrous $\beta$-lactose at $10.5,19.0$, and $21.0^{\circ}$. For $\beta$-lactose, the distinctive diffraction is at $2 \theta$ of $10.5^{\circ}$ [10]. These reflections matched with those reported for the $\beta$-lactose in the PDF 00029-1758 [28]. XRD analysis was also employed to determine the purity of the powdered samples, quantifying the relative percentage of each phase by the Rietveld method. Results are summarized in Table 2. The composition of the samples prepared at $27^{\circ} \mathrm{C}$ was $100 \%$ of $\alpha$-lactose monohydrate, while that of sample prepared at $32^{\circ} \mathrm{C}$ showed a mixture of lactose $(\alpha$ and $\beta)$. Samples prepared at 29 and $31^{\circ} \mathrm{C}$ showed a composition of pure $\beta$-lactose. These results suggest the complete conversion of the $\alpha \mathrm{L} \cdot \mathrm{H}_{2} \mathrm{O}$ into crystalline $\beta \mathrm{L}$ at temperatures of 29 and $31^{\circ} \mathrm{C}$.

The cell parameters and zero shift values were calculated from the Rietveld refinement and reported in Table 3. As observed, there are no significant differences in the cell parameters of the samples synthesized. This indicated that the
TABLE 2: Relative percentage of each phase determined by the Rietveld method.

\begin{tabular}{lcccc}
\hline $\begin{array}{l}\text { Preparation } \\
\text { temperature }\left({ }^{\circ} \mathrm{C}\right)\end{array}$ & Composition & $R_{\text {exp }}$ & $R_{\text {profile }}$ & $R_{\text {Bragg }}$ \\
\hline 27 & $100 \% \alpha \mathrm{L} \cdot \mathrm{H}_{2} \mathrm{O}$ & 2.09 & 8.3 & 6.41 \\
29 & $100 \% \beta \mathrm{L}$ & 2.05 & 13.0 & 6.07 \\
31 & $100 \% \beta \mathrm{L}$ & 2.03 & 9.1 & 6.93 \\
32 & $92 \% \alpha \mathrm{L} \cdot \mathrm{H}_{2} \mathrm{O}$ & 2.06 & 9.8 & 7.6 \\
\hline
\end{tabular}

overall crystal dimensions are maintained constant. However, the zero shift showed a slight increment between the samples synthesized at $29^{\circ} \mathrm{C}$ and the others synthesized at 27,31 , and $32^{\circ} \mathrm{C}$. This may contribute to the displacement observed in some of the reflections of the samples. Additionally, since the displacement observed in the diffractograms was not systematically presented in all the reflections, authors consider the possibility of molecular deformations in some of the crystal planes, which also may contribute to the slight shift observed. The formation of a solid solution was not considered to explain the displacement of some of the reflections, because the samples of $\beta$-lactose synthesized at 29 and $31^{\circ} \mathrm{C}$ were anhydrous, and water is necessary for the formation of the solid solution.

3.4. Thermal Characterization by Simultaneous Thermal Analysis (TGA-DSC) and Modulated Differential Scanning Calorimetry (MDSC). Figure 5 shows the TGA-DSC thermograms of the samples prepared at $27,29,31$, and $32^{\circ} \mathrm{C}$. Each graph shows two curves plotted as a function of temperature, corresponding to the weight loss (TGA) and 
TABLE 3: Cell parameters and zero shift calculated from the Rietveld refinement.

\begin{tabular}{|c|c|c|c|c|c|}
\hline Parameters & $\begin{array}{c}29^{\circ} \mathrm{C} \\
\beta \text {-Lactose }\end{array}$ & $\begin{array}{c}31^{\circ} \mathrm{C} \\
\beta \text {-Lactose }\end{array}$ & $\begin{array}{c}32^{\circ} \mathrm{C} \\
\beta \text {-Lactose }\end{array}$ & $\alpha$-Lactose & $\begin{array}{c}27^{\circ} \mathrm{C} \\
\alpha \text {-Lactose }\end{array}$ \\
\hline$a(\AA)$ & 4.96 & 4.96 & 4.95 & 4.82 & 4.83 \\
\hline$b(\AA)$ & 13.36 & 13.35 & 13.34 & 21.62 & 21.61 \\
\hline$c(\AA)$ & 10.86 & 10.85 & 10.85 & 7.78 & 7.78 \\
\hline alpha (degrees) & 90 & 90 & 90 & 90 & 90 \\
\hline beta (degrees) & 91.57 & 91.57 & 91.57 & 105.96 & 105.98 \\
\hline gamma (degrees) & 90 & 90 & 90 & 90 & 90 \\
\hline Zero shift (degrees) & 0.02 & 0.06 & \multicolumn{2}{|c|}{0.075} & 0.06 \\
\hline
\end{tabular}

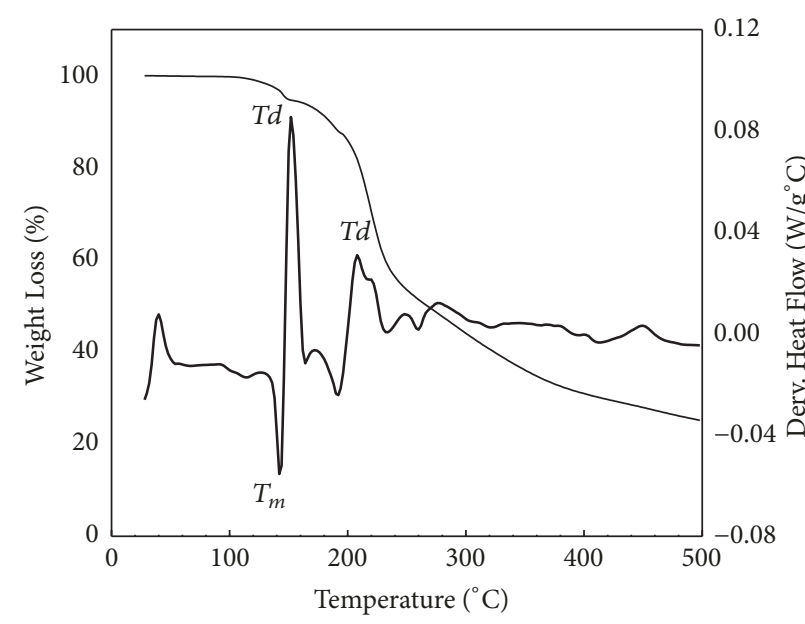

— Weight Loss $(\%)$
Derv. Heat Flow $\left(\mathrm{W} / \mathrm{g}^{\circ} \mathrm{C}\right)$

(a)

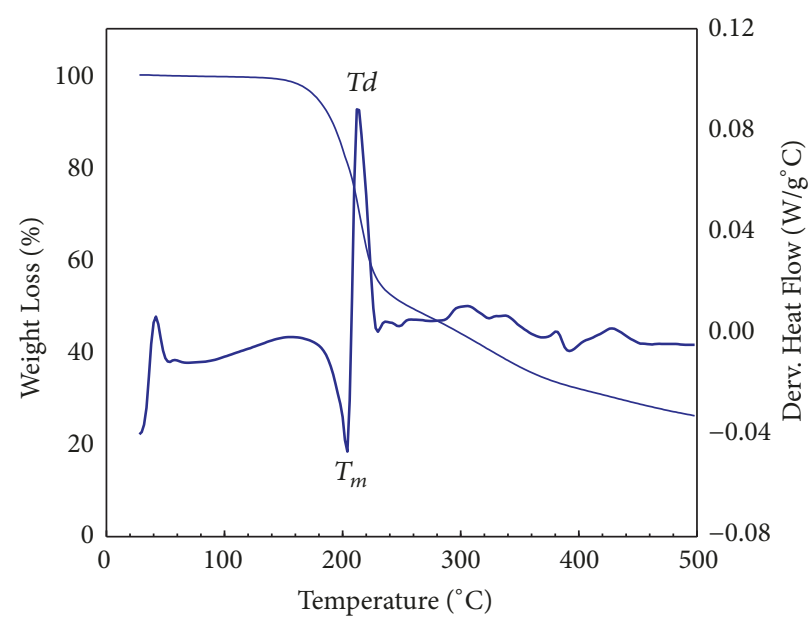

— Weight Loss (\%)

— Derv. Heat Flow $\left(\mathrm{W} / \mathrm{g}^{\circ} \mathrm{C}\right)$

(c)

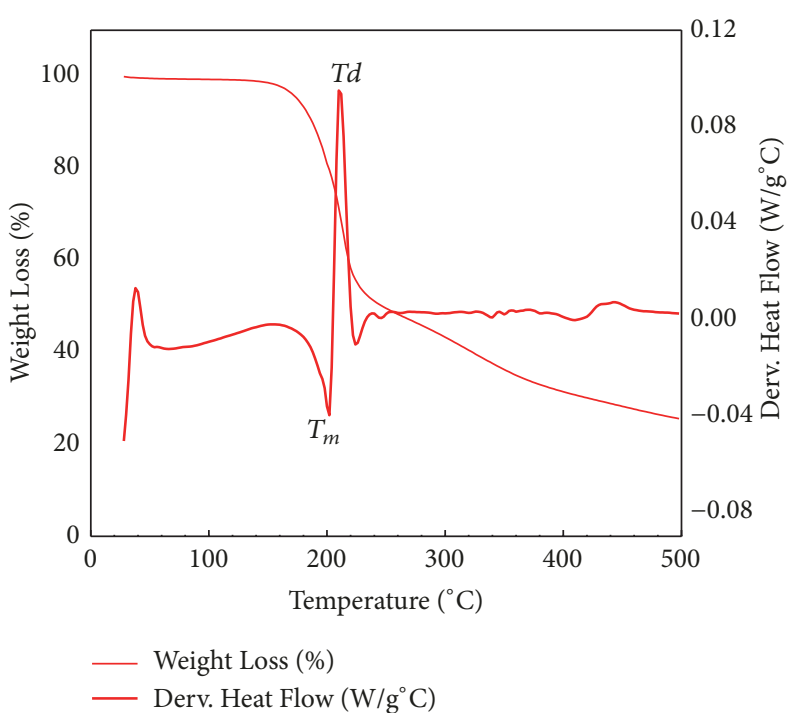

(b)

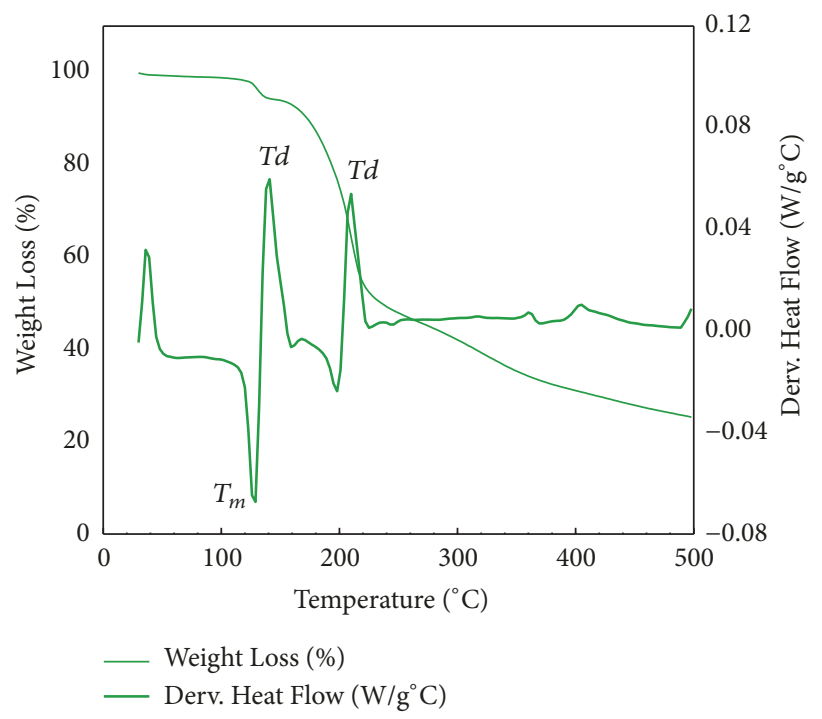

(d)

Figure 5: Simultaneous TGA-DSC of the samples synthesized at (a) 27, (b) 29 , (c) 31 , and (d) $32^{\circ} \mathrm{C}$. 
the derivative of the heat flow (DSC). The $\alpha \mathrm{L} \cdot \mathrm{H}_{2} \mathrm{O}$ samples prepared at 27 and $32^{\circ} \mathrm{C}$ (Figures 5(a) and $5(\mathrm{~d})$ ) showed several weight losses observed at $100-150^{\circ} \mathrm{C}, 150-200^{\circ} \mathrm{C}$, and $220^{\circ} \mathrm{C}$. Usually, the first loss is related to the evaporation of water chemically bonded to the lactose molecule. However, the other two weight losses cannot be assigned deliberately to the thermal decomposition of lactose or to the individual decomposition of molecules that compose it (glucose and galactose). The DSC curve showed two thermal events at 140 and $190^{\circ} \mathrm{C}$, related to the melting $\left(T_{m}\right)$ of lactose, followed by the degradation $\left(T_{d}\right)$, observed as the abrupt increase of the signal at 150 and $210^{\circ} \mathrm{C}$, respectively. On the other hand, the $\beta \mathrm{L}$ samples prepared at 29 and $31^{\circ} \mathrm{C}$ (Figure 5(b) and (c)) showed a constant baseline up to $170^{\circ} \mathrm{C}$, indicating that effectively the $\beta \mathrm{L}$ is anhydrous. In the range of $170-220^{\circ} \mathrm{C}$, there is a second mass loss (about $40 \%$ of weight loss) corresponding to the thermal decomposition of the $\beta \mathrm{L}$, which may be understood as the breaking of the glycosidic bond and the subsequent evolution of water. Above $220^{\circ} \mathrm{C}$, the glucose and galactose molecules thermally degraded, forming the products derived from the combustion of the organic matter. These observations were confirmed by the DSC curve, which showed a single melting event at $202^{\circ} \mathrm{C}$, followed by the degradation of the molecule at $210^{\circ} \mathrm{C}[9,11,18,27]$. Clearly, these results are useful for identifying the thermal events of the distinct lactose polymorphs.

Modulated differential scanning calorimetry (MDSC) is an extension of conventional DSC and is a technique widely employed for the thermal characterization of biopolymers [29-31]. In this sense, the MDSC is preferred over conventional DSC because it is more sensitive for detecting time-dependent transitions such as the glass transition temperature and other complex thermal events [29]. Figure 6 shows the MDSC thermograms of the samples prepared at $27,29,31$, and $32^{\circ} \mathrm{C}$. In the $\alpha \mathrm{L} \cdot \mathrm{H}_{2} \mathrm{O}$ obtained at $27^{\circ} \mathrm{C}$ (Figure 6(a)), three distinctive endotherms were observed at 145,185 , and $210^{\circ} \mathrm{C}$. The first corresponds to the melting of glucose units, the second to the melting of an intermediate compound, and the third to the melting of lactose molecules. The $\alpha \mathrm{L} \cdot \mathrm{H}_{2} \mathrm{O}$ obtained at $32^{\circ} \mathrm{C}$ (Figure 6(d)) showed also three thermal events, but the temperatures were presented at lower values, 120,155 , and $200^{\circ} \mathrm{C}$. The samples containing pure $\beta \mathrm{L}$ anhydrous prepared at 29 and $31^{\circ} \mathrm{C}$ (Figure 6 (b) and (c)) showed a single endotherm at 205 and $200^{\circ} \mathrm{C}$, respectively. This thermal event corresponded to the melting of the $\beta \mathrm{L}$ molecules. However, the sample prepared at $31^{\circ} \mathrm{C}$ presented a small endotherm located about $175^{\circ} \mathrm{C}$, suggesting the melting of an intermediate molecule formed as a byproduct.

Regarding the determination of $T_{g}$, the MDSC thermograms were acquired in the range of temperature of -90 to $290^{\circ} \mathrm{C}$. Usually $T_{g}$ of saccharides, disaccharides, and carbohydrate polymers is observed in this range of temperature and particularly in temperatures below $50^{\circ} \mathrm{C}$. Thus, the samples analyzed herein showed a continuous line from -90 to $50^{\circ} \mathrm{C}$, indicating the absence of the glass transition temperature. This observation is in agreement with the results of Raman and XRD and confirms that the microstructure of the samples is fully crystalline.

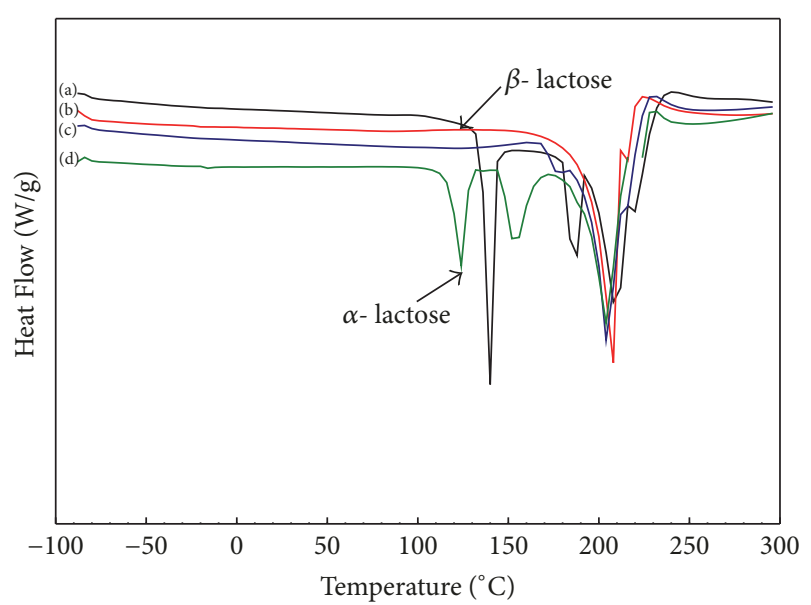

FIGURE 6: MDSC thermograms of the samples prepared at 27, 29, 31, and $32^{\circ} \mathrm{C}$.

3.5. Morphological Characterization by SEM. A scanning electron microscope (SEM) was employed to analyze the morphology and particle size lactose powders. Figure 7 shows the SEM micrographs of the samples prepared at 27, 29, 31, and $32^{\circ} \mathrm{C}$. The $\alpha \mathrm{L} \cdot \mathrm{H}_{2} \mathrm{O}$ samples prepared at 27 and $32^{\circ} \mathrm{C}$ (Figures $7(\mathrm{a})$ and $7(\mathrm{~d})$ ) exhibited an irregular morphology and particle size in the range of $10-100 \mu \mathrm{m}$. On the surface of the big particles some small particles were observed, identified as whisker-like crystals. According to Garnier et al. (2002), these crystals are formed during the crystallization of the $\alpha$-lactose suspended in methanol solution, without altering the initial morphology and composition [16]. The micrographs of the anhydrous $\beta \mathrm{L}$ samples prepared at 29 and $31^{\circ} \mathrm{C}$ (Figures $7(\mathrm{~b})$ and $7(\mathrm{c})$ ) showed similar characteristics. The most notorious feature was the smaller particle size $(1-10 \mu \mathrm{m})$ when compared with the $\alpha \mathrm{L} \cdot \mathrm{H}_{2} \mathrm{O}$ particles. Additionally, the $\beta \mathrm{L}$ anhydrous particles showed axe-type morphology with a smooth surface. Carpin et al. (2016) observed that the crystallization of $\beta \mathrm{L}$ polymorph in alcohol produced curved needle shape particles [3].

A possible explanation of the narrow operating conditions, the polymorphic transformation, and particle size decrease found herein is based on the work reported by Petit and Coquerel (1996) [32]. They studied the dehydration mechanisms of copper-8-hydroxyquinoline dihydrate to obtain the anhydrous form. According to them, the polymorphic transformations and solvate decompositions may follow a continuous mechanism or by nucleation and growth. In the continuous mechanism, the transition is carried out by the progressive reorientation and translation of the molecules in the crystal. In the nucleation and growth mechanism, the transitions are carried out on specific sites of the crystal and the progressive propagation of the crystal. Additionally, Garnier et al. (2002) reported the dehydration mechanism and the crystallization behavior of $\alpha$-lactose monohydrate to obtain stable anhydrous $\alpha$-lactose, hygroscopic $\alpha$-lactose, and $\beta$-lactose [16]. They found that despite the dehydration conditions, that is, temperature and type of solvent, the evolution of the water molecules occurs in a cooperative way, 


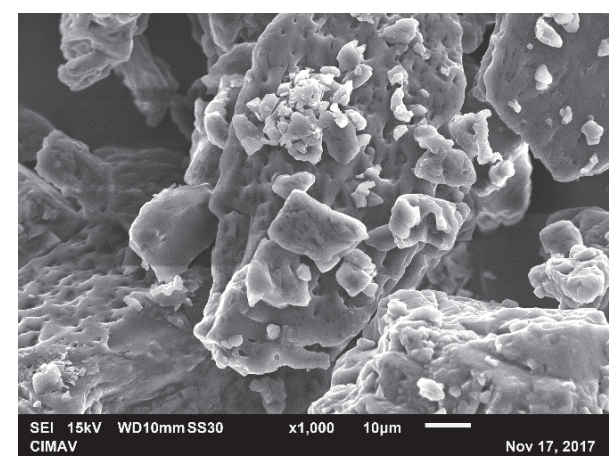

(a)

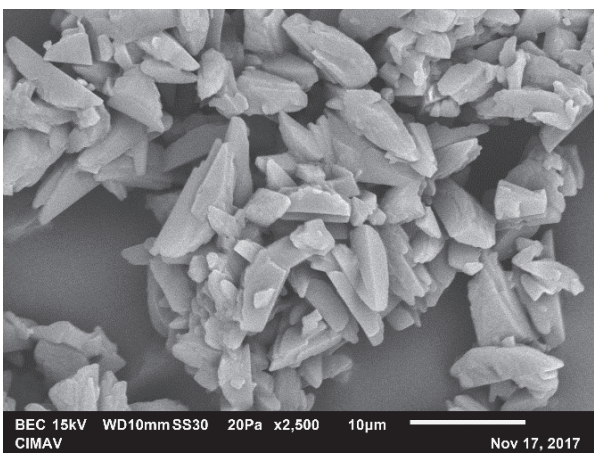

(c)

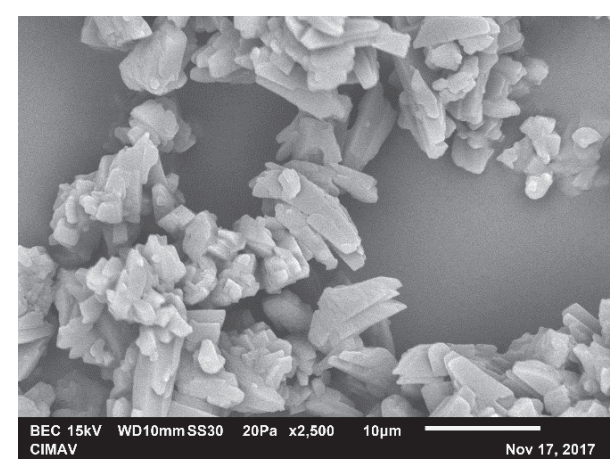

(b)

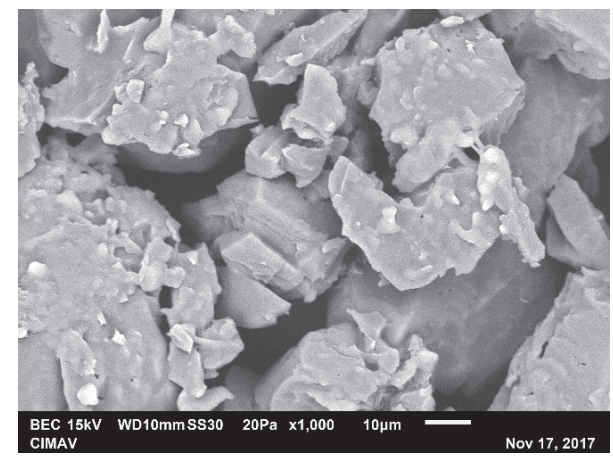

(d)

FIGURE 7: SEM micrographs of the samples prepared at (a) 27, (b) 29, (c) 31, and (d) $32^{\circ} \mathrm{C}$.

through channels parallel to the $c$ axis, providing stability to the monohydrate molecule. Therefore, the dehydration mechanism of $\alpha$-lactose monohydrate obeys a continuous model, and the evolution of water from the crystal involves the decrease in the molecular volume, which was observed as the decrease in the particle size of the $\beta$-lactose.

\section{Conclusions}

The methodology proposed in this work for obtaining pure anhydrous $\beta$-lactose $(\beta \mathrm{L})$ involved the static reaction (without stirring) of $\alpha$-lactose monohydrate $\left(\alpha \mathrm{L} \cdot \mathrm{H}_{2} \mathrm{O}\right)$ in a basic alcoholic solution at controlled conditions of temperature. By Fourier transform infrared (FTIR) and Raman spectroscopies, it was found that the full conversion of $\alpha \mathrm{L} \cdot \mathrm{H}_{2} \mathrm{O}$ into anhydrous $\beta \mathrm{L}$ proceeds only in a narrow temperature range of $29-31^{\circ} \mathrm{C}$. Although the reaction time was longer than in other reported works, the obtained $\beta \mathrm{L}$ composition was pure as determined by the Rietveld refinement of the $\mathrm{X}$-ray diffraction (XRD) patterns. Thermal analysis (simultaneous TGADSC, and MDSC) confirmed these results, after observing a single melting event at $204^{\circ} \mathrm{C}$, followed by the thermal degradation at $210^{\circ} \mathrm{C}$. The thermal characterization of the samples prepared at 27 and $32^{\circ} \mathrm{C}$ showed the formation of mixtures of $\alpha \mathrm{L} \cdot \mathrm{H}_{2} \mathrm{O}$ and $\beta \mathrm{L}$, since two melting events were observed at 146 and $200^{\circ} \mathrm{C}$. The observation of the powders by scanning electron microscopy showed a regular axe-like morphology with a smooth surface for the $\beta \mathrm{L}$ samples, while $\alpha \mathrm{L} \cdot \mathrm{H}_{2} \mathrm{O}$ showed irregular shape particles with sizes of several tens of microns. Clearly, with this simple methodology, it was possible to obtain pure, crystalline, and anhydrous $\beta \mathrm{L}$ at mild conditions of temperature.

\section{Conflicts of Interest}

The authors declare that there are no conflicts of interest regarding the publication of this paper.

\section{Acknowledgments}

Ana L. López-Pablos is grateful to the Consejo Nacional de Ciencia y Tecnología (CONACyT) in Mexico for the financial support provided during her Ph.D. through the scholarship no. 166918.

\section{References}

[1] V. H. Holsinger, "Physical and chemical properties of lactose," in Advanced Dairy Chemistry, P. F. Fox, Ed., vol. 3, pp. 1-38, Springer US, 1997.

[2] K. J. Burrington, "Food applications for whey permeate," Dairy Pipeline, vol. 17, pp. 1-5, 2007.

[3] M. Carpin, H. Bertelsen, J. K. Bech, R. Jeantet, J. Risbo, and P. Schuck, "Caking of lactose: A critical review," Trends in Food Science \& Technology, vol. 53, pp. 1-12, 2016.

[4] A. H. J. Paterson, "Production and uses of lactose," in Advanced Dairy Chemistry, P. L. H. McSweeney and P. F. Fox, Eds., pp. 105-120, Springer Science, LLC, 2009. 
[5] B. Albertini, C. Cavallari, N. Passerini, M. L. GonzálezRodríguez, and L. Rodriguez, "Evaluation of $\beta$-lactose, PVP K12 and PVP K90 as excipients to prepare piroxicam granules using two wet granulation techniques," European Journal of Pharmaceutics and Biopharmaceutics, vol. 56, no. 3, pp. 479-487, 2003.

[6] V. H. Holsinger, "Lactose," in Fundamentals of Dairy Chemistry, N. P. Wong, R. Jenness, M. Keeney, and E. H. Marth, Eds., pp. 279-342, Springer US, 1988.

[7] S. Ziffels and H. Steckel, "Influence of amorphous content on compaction behaviour of anhydrous $\alpha$-lactose," International Journal of Pharmaceutics, vol. 387, no. 1-2, pp. 71-78, 2010.

[8] Y. D. Listiohadi, J. A. Hourigan, R. W. Sleigh, and R. J. Steele, "Properties of lactose and its caking behaviour," Australian Journal of Dairy Technology, vol. 60, no. 1, pp. 33-52, 2005.

[9] J. Chen, J. Wang, R. Li, A. Lu, and Y. Li, "Thermal and X-ray diffraction analysis of lactose polymorph," Procedia Engineering, vol. 102, pp. 372-378, 2015.

[10] J. H. Kirk, S. E. Dann, and C. G. Blatchford, "Lactose: A definitive guide to polymorph determination," International Journal of Pharmaceutics, vol. 334, no. 1-2, pp. 103-114, 2007.

[11] L. O. Figura and M. Epple, "Anhydrous $\alpha$-lactose A study with DSC and TXRD," Journal of Thermal Analysis and Calorimetry, vol. 44, no. 1, pp. 45-53, 1995.

[12] A. Olano and J. J. Ríos, "Treatment of lactose with alkaline methanolic solutions: production of beta-lactose from alphalactose hydrate," Journal of Dairy Science, vol. 61, no. 3, pp. 300302, 1978.

[13] F. W. Parrish, K. D. Ross, and T. D. Simpson, "Formation of $\beta$ lactose from $\alpha$ - and $\beta$-lactose octaacetates, and from $\alpha$-lactose monohydrate," Carbohydrate Research, vol. 71, no. 1, pp. 322326, 1979.

[14] A. Olano, "Procedimiento para la obtencion de $\beta$-lactosa," Patent No 468792, Ministerio de Industria de España, Madrid, España, 1978.

[15] F. W. Parrish, K. D. Ross, and K. M. Valentine, "Formation of $\beta$-lactose from the stable forms of anhydrous $\alpha$-lactose," Journal of Food Science, vol. 45, no. 1, pp. 68-70, 1980.

[16] S. Garnier, S. Petit, and G. Coquerel, "Dehydration mechanism and crystallisation behaviour of lactose," Journal of Thermal Analysis and Calorimetry, vol. 68, no. 2, pp. 489-502, 2002.

[17] R. A. Young, The Rietveld Method, International Union of Crystallography, Oxford Science Publications, Oxford, UK, 1st edition, 1996.

[18] Y. Listiohadi, J. A. Hourigan, R. W. Sleigh, and R. J. Steele, "Thermal analysis of amorphous lactose and $\sigma$-lactose monohydrate," Dairy Science \& Technology, vol. 89, no. 1, pp. 43-67, 2009.

[19] British Pharmacopoeia (BP), Medicinal and Pharmaceutical Substances, vol. 1, The Stationery Office, 2001.

[20] K. P. Norris and J. E. S. Greenstreet, "Infra-red absorption spectra of casein and lactose," Nature, vol. 181, no. 4604, pp. 265266, 1958.

[21] G. D. Smith and R. J. H. Clark, "Raman microscopy in archaeological science," Journal of Archaeological Science, vol. 31, no. 8, pp. 1137-1160, 2004.

[22] E. Wiercigroch, E. Szafraniec, K. Czamara et al., "Raman and infrared spectroscopy of carbohydrates: A review," Spectrochimica Acta Part A: Molecular and Biomolecular Spectroscopy, vol. 185, pp. 317-335, 2017.

[23] B. M. Murphy, S. W. Prescott, and I. Larson, "Measurement of lactose crystallinity using Raman spectroscopy," Journal of
Pharmaceutical and Biomedical Analysis, vol. 38, no. 1, pp. 186190, 2005.

[24] M. J. Márquez, A. B. Brizuela, L. Davies, and S. A. Brandán, "Spectroscopic and structural studies on lactose species in aqueous solution combining the HATR and Raman spectra with SCRF calculations," Carbohydrate Research, vol. 407, pp. 34-41, 2015.

[25] P. H. Rodrigues Júnior, K. De Sá Oliveira, C. E. R. D. Almeida et al., "FT-Raman and chemometric tools for rapid determination of quality parameters in milk powder: Classification of samples for the presence of lactose and fraud detection by addition of maltodextrin," Food Chemistry, vol. 196, pp. 584-588, 2016.

[26] The International Centre for Diffraction Data (ICCD) PDF No. 00-024-1783.

[27] Á. Gombás, I. Antal, P. Szabó-Révész, S. Marton, and I. Erõs, "Quantitative determination of crystallinity of alpha-lactose monohydrate by Near Infrared Spectroscopy (NIRS)," International Journal of Pharmaceutics, vol. 256, no. 1-2, pp. 25-32, 2003.

[28] The International Centre for Diffraction Data (ICCD) PDF No. 00-029-1758.

[29] E. Verdonck, K. Schaap, and L. C. Thomas, "A discussion of the principles and applications of Modulated Temperature DSC (MTDSC)," International Journal of Pharmaceutics, vol. 192, no. 1, pp. 3-20, 1999.

[30] M. S. Rahman, "State diagram of foods: Its potential use in food processing and product stability," Trends in Food Science \& Technology, vol. 17, no. 3, pp. 129-141, 2006.

[31] S. S. Sablani, R. M. Syamaladevi, and B. G. Swanson, "A review of methods, data and applications of state diagrams of food systems," Food Engineering Reviews, vol. 2, no. 3, pp. 168-203, 2010.

[32] S. Petit and G. Coquerel, "Mechanism of several solid-solid transformations between dihydrated and anhydrous copper(II) 8-hydroxyquinolinates. Proposition for a unified model for the dehydration of molecular crystals," Chemistry of Materials, vol. 8, no. 9, pp. 2247-2258, 1996. 


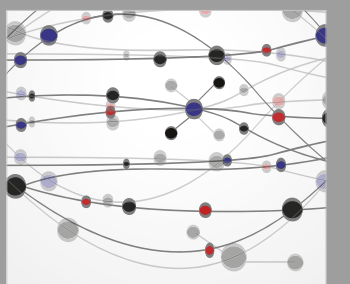

The Scientific World Journal
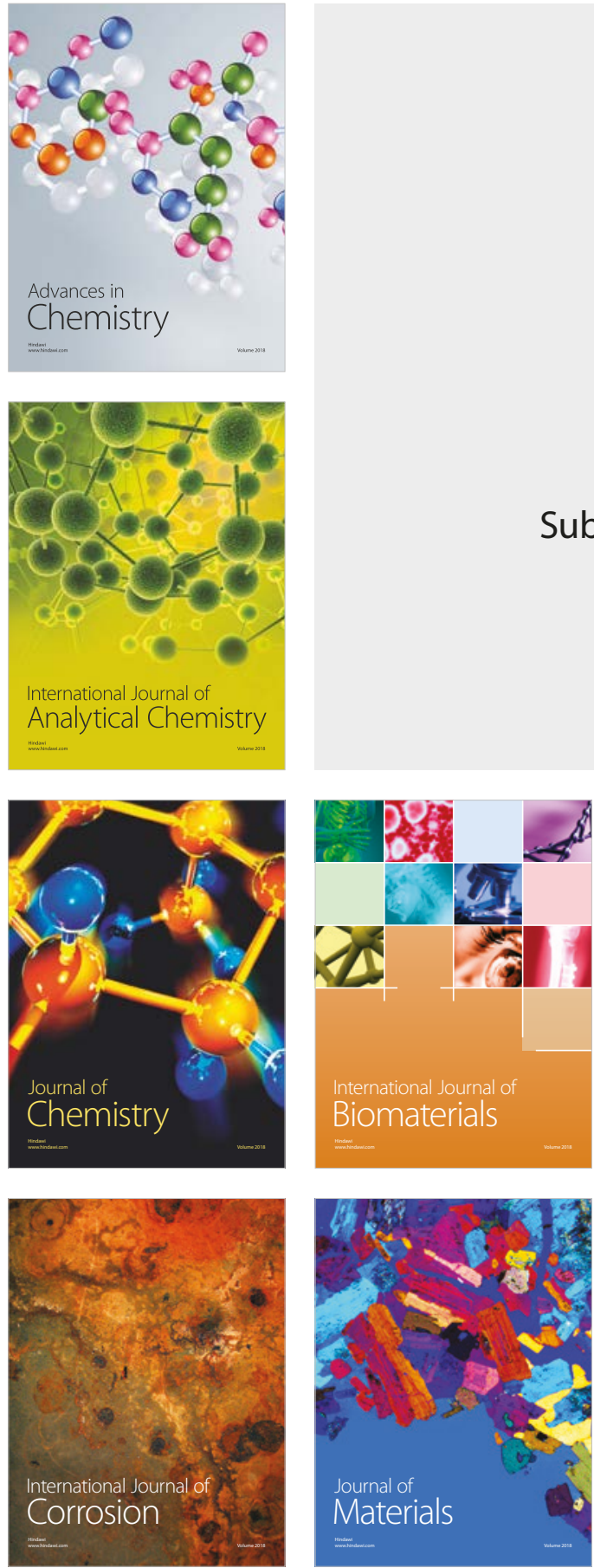

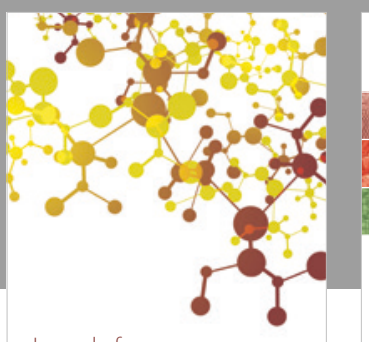

Journal of

Applied Chemistry
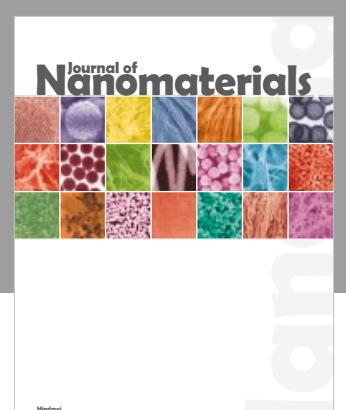

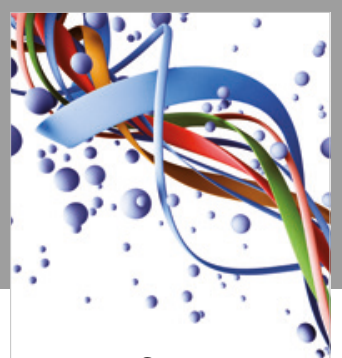

Scientifica

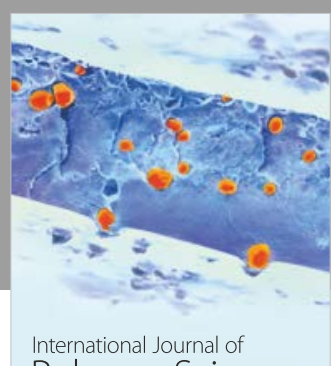

Polymer Science

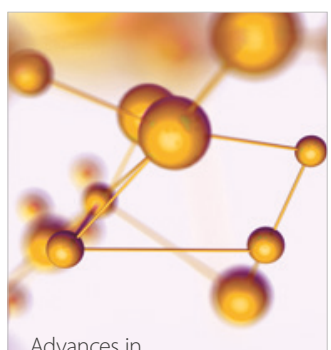

Physical Chemistry
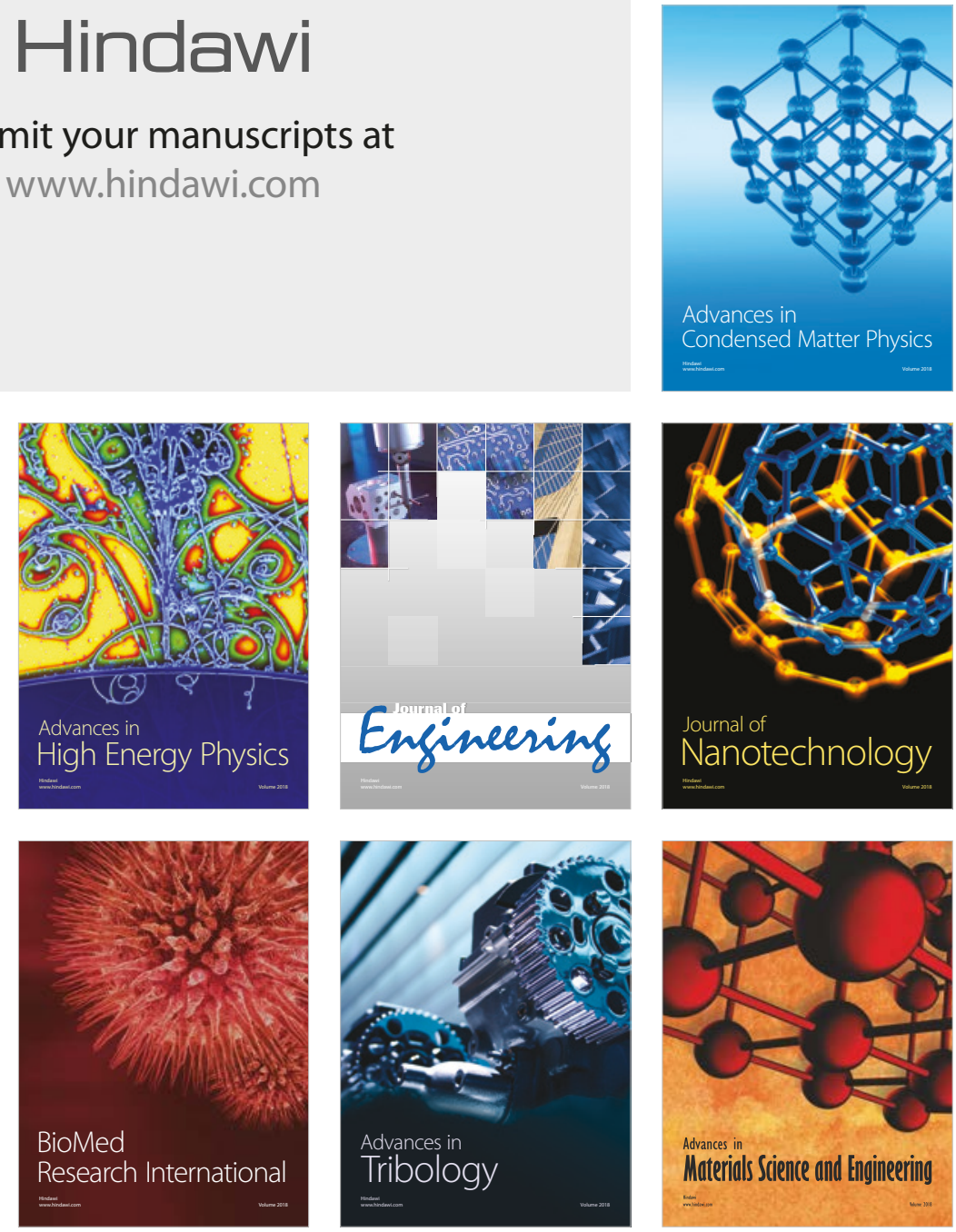